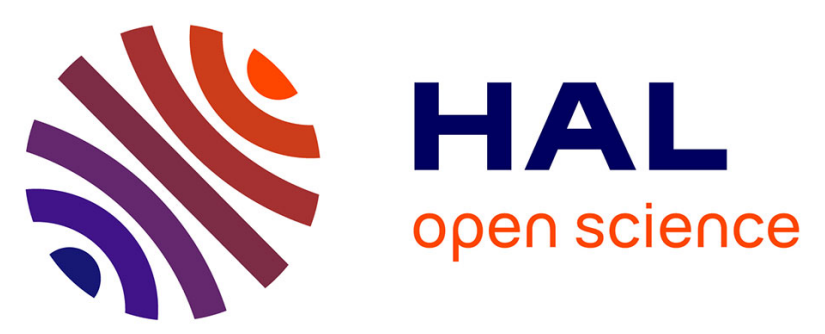

\title{
DNA incorporation of 6-thioguanine nucleotides during maintenance therapy of childhood acute lymphoblastic leukaemia and non-Hodgkin lymphoma
}

Rikke L. Hedeland, Kristian Hvidt, Jacob Nersting, Susanne Rosthøj, Kim Dalhoff, Birgitte Lausen, Kjeld Schmiegelow

\section{To cite this version:}

Rikke L. Hedeland, Kristian Hvidt, Jacob Nersting, Susanne Rosthøj, Kim Dalhoff, et al.. DNA incorporation of 6-thioguanine nucleotides during maintenance therapy of childhood acute lymphoblastic leukaemia and non-Hodgkin lymphoma. Cancer Chemotherapy and Pharmacology, 2009, 66 (3), pp.485-491. 10.1007/s00280-009-1184-5 . hal-00552479

\author{
HAL Id: hal-00552479 \\ https://hal.science/hal-00552479
}

Submitted on 6 Jan 2011

HAL is a multi-disciplinary open access archive for the deposit and dissemination of scientific research documents, whether they are published or not. The documents may come from teaching and research institutions in France or abroad, or from public or private research centers.
L'archive ouverte pluridisciplinaire HAL, est destinée au dépôt et à la diffusion de documents scientifiques de niveau recherche, publiés ou non, émanant des établissements d'enseignement et de recherche français ou étrangers, des laboratoires publics ou privés. 


\title{
DNA incorporation of 6-thioguanine nucleotides during maintenance therapy of childhood acute lymphoblastic leukaemia and non-Hodgkin lymphoma
}

\author{
Rikke L. Hedeland · Kristian Hvidt · Jacob Nersting • \\ Susanne Rosthøj · Kim Dalhoff • Birgitte Lausen • \\ Kjeld Schmiegelow
}

Received: 29 July 2009 / Accepted: 11 November 2009 / Published online: 3 December 2009

(C) Springer-Verlag 2009

\begin{abstract}
Purpose To explore the DNA incorporation of 6-thioguanine nucleotide levels (DNA-6TGN) during 6-mercaptopurine (6MP) therapy of childhood acute lymphoblastic leukaemia (ALL) and non-Hodgkin lymphoma (NHL) and its relation to erythrocyte levels of their metabolites: 6thioguanine-nucleotides (E-6TGN), methylated metabolites (E-MeMP), Methotrexate polyglutamates (E-MTX), and to thiopurine methyltransferase activity (TPMT).

Methods We studied these metabolites in 229 blood samples from 18 children with ALL $(N=16)$ or NHL $(N=2)$ on 6MP/Methotrexate maintenance therapy.

Results DNA-6TGN levels were significantly correlated to E-6TGN $\left(r_{\mathrm{p}}=0.66, p=0.003\right)$ with a trend to reach a plateau at high E-6TGN levels. To explore the relative
\end{abstract}

R. L. Hedeland · K. Hvidt · J. Nersting · B. Lausen ·

K. Schmiegelow $(\square)$

The Section for Pediatric Hematology and Oncology,

Pediatric Clinic II, The Juliane Marie Center,

The University Hospital, Rigshospitalet,

2100 Copenhagen, Denmark

e-mail: kjeld.schmiegelow@ @h.regionh.dk

S. Rosthøj

Department of Biostatistics,

University of Copenhagen, 1014 Copenhagen, Denmark

K. Dalhoff

Department of Clinical Pharmacology,

Bispebjerg Hospital, 2400 Copenhagen, Denmark

K. Schmiegelow

The Faculty of Medicine, Institute of Gynecology, Obstetrics and Pediatrics, University of Copenhagen,

2200 Copenhagen, Denmark
DNA incorporation of 6TGN in relation to cytosol 6TGN levels, a DNA-6TGN index was calculated as DNA-6TGN/ E-6TGN. The DNA-6TGN index was inversely correlated to E-6TGN $\left(r_{\mathrm{p}}=-0.58, p=0.012\right)$, which implies that with increasing levels of E-6TGN relatively less 6TGN are incorporated into DNA. E-MeMP levels were correlated to the DNA-TGN index $\left(r_{\mathrm{p}}=0.60, p=0.008\right)$, indicating that high levels of MeMP result in enhanced DNA-6TGN incorporation, possibly due to inhibition of purine de novo synthesis, mediated by some of the methylated 6MP metabolites.

Conclusions DNA-6TGN may prove to be a more relevant pharmacokinetic parameter for monitoring 6MP treatment intensity than the previously used erythrocyte 6MP metabolites levels. Prospective clinical trials are needed to evaluate the usefulness of DNA-6TGN for individual dose adjustments.

Keywords Acute lymphoblastic leukaemia . Non-Hodgkin lymphoma - Maintenance therapy · Pharmacokinetics $\cdot$ Paediatric cancer $\cdot$ Paediatric pharmacology

\section{Introduction}

Acute lymphoblastic leukaemia (ALL) is the most common cancer in childhood [1]. During the last 30 years, the prognosis has improved dramatically and most collaborative groups in Europe and the United States have obtained overall survival rates above $80 \%$ [1]. A crucial part of the ALL and non-B non-Hodgkin lymphoma (NHL) protocols is maintenance therapy with daily oral 6-mercaptopurine (6MP) and weekly Methotrexate (MTX) until 2-3 years from the time of diagnosis. 
Due to large interindividual variations in the metabolism of these antimetabolites, the response to standard 6MP/ MTX doses varies significantly, and 6MP/MTX maintenance therapy of childhood ALL and NHL is usually adjusted and targeted to specified degrees of bone marrow suppression [2, 3]. 6MP is a pro-drug with no intrinsic anticancer activity. The cytotoxic action of $6 \mathrm{MP}$ is mediated by two classes of metabolites-the 6-thioguanine nucleotides (6TGN) and the methylated metabolites of 6MP (MeMP) (Fig. 1). 6TGN function as substrates for the DNA-polymerase by which 6TGN can be incorporated into DNA instead of guanosine or adenosine, and occasionally be mismatched to thymidine [4]. 6TGN-thymidine base pairs may activate the post-replicative mismatch repair systems, and unsuccessful attempts to correct 6TGN-thymidine mispairing may lead to DNA strand breaks and other chromosome aberrations [4]. Some of the methylated 6MP metabolites, most notably methyl thioinosine monophosphate (Me-TIMP), are strong inhibitors of purine de novo synthesis [5].

The pharmacokinetics and the response to 6MP therapy are influenced by common single nucleotide polymorphisms in the activity of the enzyme thiopurine methyltransferase (TPMT) [6, 7] (Fig. 1). As a result of these polymorphisms [6], 89\% of white populations are homozygous for high TPMT activity (TPMT, wild type) and, therefore, have significant lower erythrocyte levels of 6TGN (E-6TGN) than the remaining $11 \%$ heterozygous and the 1 in 300 enzyme deficient of the population, who carries one or two low activity alleles, respectively.

The majority of clinical studies have used E-6TGN as a surrogate parameter for DNA-6TGN levels in nucleated cells [5, 8-11], and some [8, 11], although not all studies [10], have found E-6TGN to be related to the risk of relapse and myelotoxicity.
TPMT activity competes with the formation of 6TGN, as it methylates thiopurines (especially 6MP) and some of their metabolites. Most of the methylated metabolites are relatively non-toxic, although some, e.g. methyl thioinosine monophosphate (Me-TIMP), are known to be powerful inhibitors of the purine de novo synthesis [5]. Since the levels of MeMP increase with higher dose of 6MP [9], such 6MP dose increments in TPMT homozygous patients could potentially lead to enhanced DNA-6TGN incorporation due to inhibition of purine de novo synthesis, which has been indicated by in vitro studies [5]. However, clinical studies of the significance of this mechanism have been lacking.

In a preliminary exploration of whether DNA-6TGN could be a useful parameter for monitoring thiopurine therapy, we have in the present study mapped the distribution of DNA-6TGN and the relative DNA-incorporation of 6TGN (DNA-6TGN index) in a cohort of children on 6MP/ MTX maintenance therapy and their relation to TPMT activity and to erythrocyte levels of 6TGN (E-6TGN), MeMP (E-MeMP), and MTX polyglutamates (E-MTX), since these pharmacological parameters by many groups have been used as surrogate parameters for the 6MP and MTX metabolism in nucleated cells and for treatment intensity [9-12].

This pharmacokinetic study did not include correlations to drug doses, blood counts, or liver parameters.

\section{Materials and methods}

\section{Patients}

The samples were collected and stored from March 1999 to March 2000 after approval by the Ethical Committee of
Fig. 1 The main metabolic pathways and metabolites of 6MP. Purine salvage pathway is limited in malignant lymphoblasts. Inhibition of purine de novo synthesis by some of the methylated mercaptopurine metabolites (including MeTIMP) may thus increase 6TGN incorporation into DNA. TPMT thiopurine methyltransferase, $H G P R T$ hypoxanthine guanine phosphoribosyltransferase, $6 M P$ 6-mercaptopurine, 6TGN 6thioguanine-nucleotides

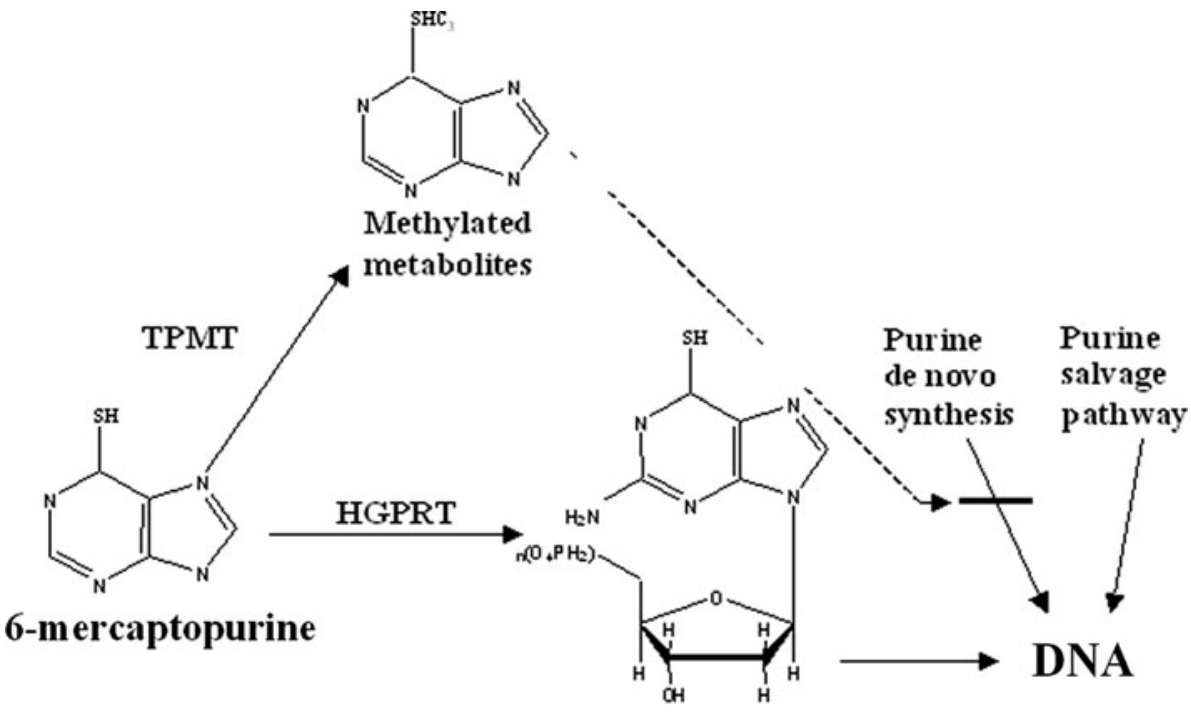

6-thioguanine nucleotides 
Copenhagen and Frederiksberg municipalities (no. V.200. 2080/91) and informed consent by the parents according to the Declaration of Helsinki. The samples were subsequently thawed and analysed as part of the present study. We measured DNA-6TGN at a median of 10 times (range 3-34 times) in 5 girls and 13 boys with ALL $(N=16)$ or NHL $(N=2)$ on 6MP/MTX maintenance therapy attending the University Hospital, Rigshospitalet, Copenhagen. The patients were between 18 months and 12 years of age at diagnosis, in first remission, and had three or more stored blood samples. Their median age was 6.1 years at their first DNA-6TGN measurement (range 1.5-12.5 years) (Table 1).

All patients were TPMT-genotyped for the $460 \mathrm{G}>\mathrm{A}$ and $719 \mathrm{~A}>\mathrm{G}$ low activity polymorphisms. 15 patients were homozygous for the high activity allele, and three patients were TPMT heterozygous.

\section{Therapy}

All patients were treated according to the NOPHO ALL-92 or NHL-95 protocols [13] and started maintenance therapy with oral doses of $75 \mathrm{mg} / \mathrm{m}^{2} /$ day for $6 \mathrm{MP}$ and $20 \mathrm{mg} / \mathrm{m}^{2} /$ week for MTX, which subsequently were titrated to a target leukocyte count of $1.5-3.5 \times 10^{9} / 1$.

Table 1 Data on the included 18 patients

\begin{tabular}{llrrll}
\hline Patients & Gender & $\begin{array}{l}\text { Age at } \\
\text { diagnosis }\end{array}$ & $\begin{array}{l}\text { Samples } \\
(N)\end{array}$ & Genotype & Disease \\
\hline 1 & M & 5.81 & 10 & Homozygous & ALL \\
2 & M & 6.39 & 3 & Homozygous & ALL \\
3 & M & 5.56 & 10 & Homozygous & ALL \\
4 & M & 3.56 & 34 & Homozygous & ALL \\
5 & F & 7.26 & 16 & Homozygous & ALL \\
6 & M & 4.10 & 17 & Homozygous & ALL \\
7 & F & 11.94 & 3 & Homozygous & ALL \\
8 & F & 1.50 & 8 & Homozygous & ALL \\
9 & M & 10.55 & 6 & Homozygous & NHL \\
10 & M & 6.78 & 23 & Heterozygous & NHL \\
11 & M & 2.15 & 20 & Heterozygous & ALL \\
12 & M & 10.19 & 9 & Homozygous & ALL \\
13 & M & 3.90 & 9 & Homozygous & ALL \\
14 & F & 9.79 & 21 & Homozygous & ALL \\
15 & M & 4.50 & 8 & Homozygous & ALL \\
16 & M & 12.52 & 13 & Heterozygous & ALL \\
17 & M & 4.23 & 15 & Homozygous & ALL \\
18 & F & 4.68 & 4 & Homozygous & ALL \\
Total & & 6.07 & 229 & & \\
\hline & & & & & \\
\hline
\end{tabular}

\section{Chemicals}

Nuclease P1 was purchased from Boehringer Mannheim $\mathrm{GmbH}$, Mannheim, Germany; Mercurycellulose was purchased from Clauson-Kaas, Farum, Denmark; and all other reagents were purchased from Sigma Chemical Company, St. Louis, USA.

Leukocyte DNA 6-thioguanine nucleotide (DNA-6TGN) assay

\section{DNA isolation}

Leukocytes were isolated from $6 \mathrm{ml}$ whole blood. Leukocyte DNA was isolated by the method described by Miller [14] by means of QIAamp blood kit (purchased from QIAGEN, Düsseldorf, Germany). The isolated DNA was resuspended in $400 \mu \mathrm{l}$ distilled water. DNA concentration and purity were determined by spectroscopy from absorbance at 260 and $280 \mathrm{~nm}$.

\section{TGN extraction from DNA and 6TGN quantification}

DNA was digested into free nucleotides with $80 \mu \mathrm{l}$ of a $\mathrm{P}_{1}$ nuclease/acid phosphatase solution for a minimum of $1 \mathrm{~h}$ at $42^{\circ} \mathrm{C}$. $6 \mathrm{TGN}$ were then selectively extracted from the natural nucleotides by mercury cellulose extraction in parallel with an external standard curve [15]. The extracted 6TGN in the sample and the standards were quantified by high performance liquid chromatography (HPLC) with UV detection by a minor modification of the method described by Bruunshuus and Schmiegelow [15] designed to measure 6TGN in erythrocytes. The procedure was performed in the following steps: (1) measurement of OD at 260 and $280 \mathrm{~nm}$. (2) $195 \mu \mathrm{l}$ DNA sample was added to $80 \mu \mathrm{l}$ of P1 nuclease/acid phosphatase. (3) The sample was incubated for minimum $1 \mathrm{~h}$ at $42^{\circ} \mathrm{C}$. (4) The sample was transferred to the HPLC-UV for quantification of the amount of DNA$6 \mathrm{TGN}$ at wavelength $342 \mathrm{~nm}$. All measurements were done in duplicates. The coefficient of variation of the analysis was less than $10 \%$ with an intra-assay variation of $4 \%$. Given a blood sample of $10 \mathrm{ml}$, a white blood cell count of $3 \times 10^{9} / 1$, and complete DNA-extraction, the sensitivity limit for DNA-6TGN incorporation is a ratio of 1:24,154 6TGN per DNA nucleotides.

Erythrocyte 6-mercaptopurine metabolites, Methotrexate and TPMT phenotyping

All analyses of E-6TGN, E-MeMP (which primarily is Me-TIMP), E-TPMT activity, and E-MTX were performed at the laboratory for Pediatric Oncology, The University 
Hospital, Rigshospitalet, Copenhagen as part of a standard monitoring program of maintenance therapy [15-17].

Statistics

The associations between the parameters of interest were investigated by the use of subject means. To account for the different number of measurements on each patient, all analyses were weighted by the number of measurements for the relevant patient. For continuous variables, the correlation between variables was assessed by the weighted Pearson correlation coefficient $\left(r_{\mathrm{p}}\right)$ [18], whereas the relations between continuous and dichotomous variables were explored by weighted two-sample $t$ tests. When needed, continuous variables were log-transformed to obtain normality.

To explore the relative DNA-incorporation of 6TGN in relation to cytosol 6TGN, a DNA-6TGN index was calculated as DNA-6TGN/E-6TGN.

The median incorporation ratio of 6TGN per DNA nucleotide was calculated as the median of the 229 blood samples.

The relationship between E-6TGN and DNA-6TGN was explored by the Loess smoothing, non-linear regression curve fitting method [19].

In all analyses, two-sided $p$ values $<0.05$ were regarded as being significant. Data analysis was performed with SAS software package version 9.1 and $\mathrm{R}$ software package version 2.8.0.

\section{Results}

Of the 305 samples available, the DNA-6TGN could not be quantified in 76 samples due to lack of sufficient amounts of DNA or DNA-6TGN levels below the detection limit. These 76 blood samples all had measurable levels of meanE-6TGN, meanE-MeMP, and meanE-MTX, which exclude non-compliance as an explanation for unmeasurable DNA-6TGN.

The mean DNA concentration for the TPMT homozygote patients was $0.88 \mu \mathrm{g} / \mu \mathrm{l}(168 \mu \mathrm{g})$ and $0.84 \mu \mathrm{g} / \mu \mathrm{l}$ $(132.95 \mu \mathrm{g})$ for the TPMT heterozygote patients.

The median E-6TGN level for the remaining 229 samples was $284 \mathrm{nmol} / \mathrm{mmol} \mathrm{hb}$ (range 51-864). The median DNA-6TGN level was $0.52 \mathrm{pmol} 6 \mathrm{TGN} / \mu \mathrm{g}$ DNA (range 0.05-2.12) corresponding to a median incorporation ratio of 1:4,949 6TGN per DNA nucleotides (range 1:60,300 to $1: 1,502)$.

meanDNA-6TGN levels were not related to age $\left(r_{\mathrm{p}}=-0.13, p=0.63\right)$ or gender $(p=0.46)$.

The meanDNA-6TGN level was $0.48 \mathrm{pmol} / \mu \mathrm{g}$ DNA (range 0.26-0.91) (TPMT-homozygous patients: $0.49 \mathrm{pmol} / \mu \mathrm{g}$
DNA, TPMT heterozygous patients: $0.66 \mathrm{pmol} / \mu \mathrm{g}$ DNA). meanDNA-6TGN levels were significantly correlated to meanE-6TGN $\left(r_{\mathrm{p}}=0.67, p=0.003\right)$ with a trend to reach a plateau at high mE-6TGN levels (Fig. 2). This correlation was virtually unchanged, when TPMT heterozygous patients were excluded $\left(r_{\mathrm{p}}=0.66, p=0.008\right)$.

The meanDNA-6TGN index was inversely correlated to meanE-6TGN $\left(r_{\mathrm{p}}=-0.58, p=0.011\right)$, which implies that with increasing levels of E-6TGN relatively less 6TGN were incorporated into DNA (Fig. 3).

The median DNA-6TGN index was $0.18 \mathrm{pmol} / \mu \mathrm{g} / \mathrm{nmol} /$ mmol DNA (range 0.032-0.74). The median E-MeMP level was $5,579 \mathrm{nmol} / \mathrm{mmol} \mathrm{hb}$ (range 172-25,830) (TPMT homozygous patients: $6,705 \mathrm{nmol} / \mathrm{mmol} \mathrm{hb}$, TPMT heterozygous patient: $1,628 \mathrm{nmol} / \mathrm{mmol} \mathrm{hb}$ ) (Table 2).

meanE-MeMP levels were significantly correlated to the mDNA-6TGN index $\left(r_{\mathrm{p}}=0.49, p=0.033\right)$, which indicates
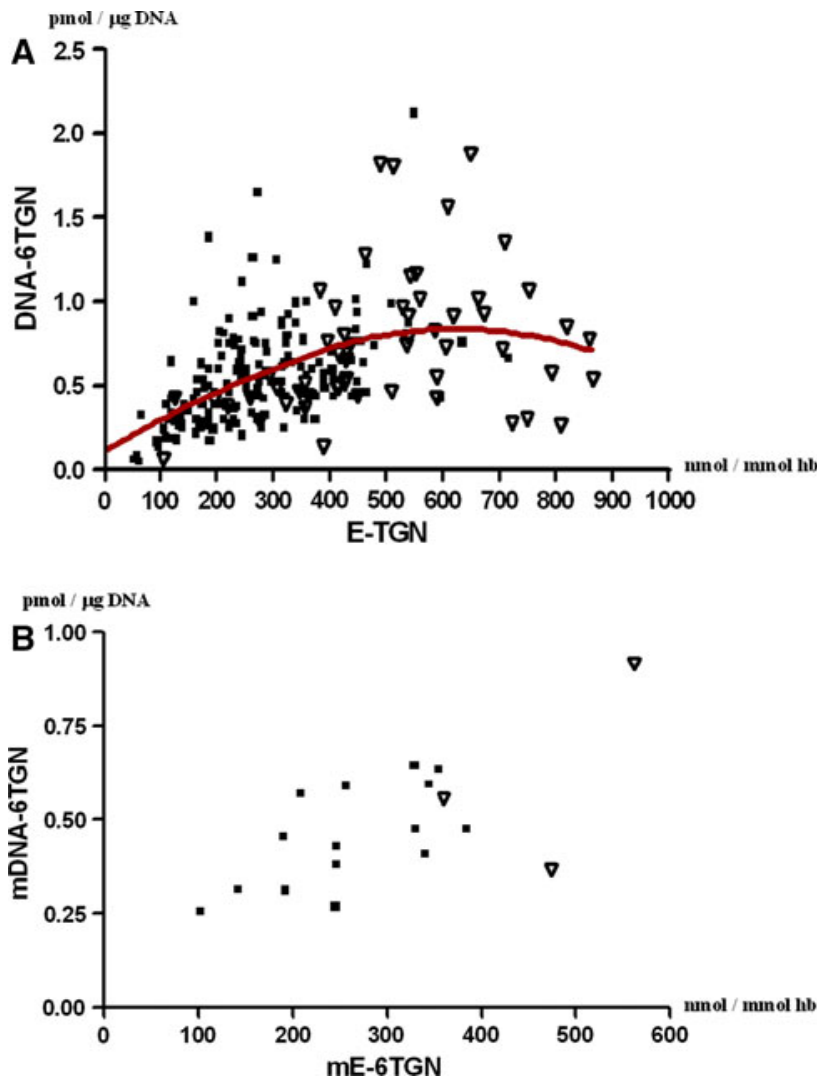

Fig. 2 a E-6TGN versus DNA-6TGN in individual blood samples. The solid line is a Loess smoothing curve, describing the relationship between E-6TGN and DNA-6TGN. DNA-6TGN levels were significantly correlated to E-6TGN, with a trend to reach a plateau at high E-6TGN levels. Inverted triangle TPMT heterozygous patients, filled square TPMT homozygous patients. b mE-6TGN versus mDNA6TGN. mDNA-6TGN levels were significantly correlated to mE6TGN, with a trend to reach a plateau at high mE-6TGN levels. Inverted triangle TPMT heterozygous patients, filled square TPMT homozygous patients 

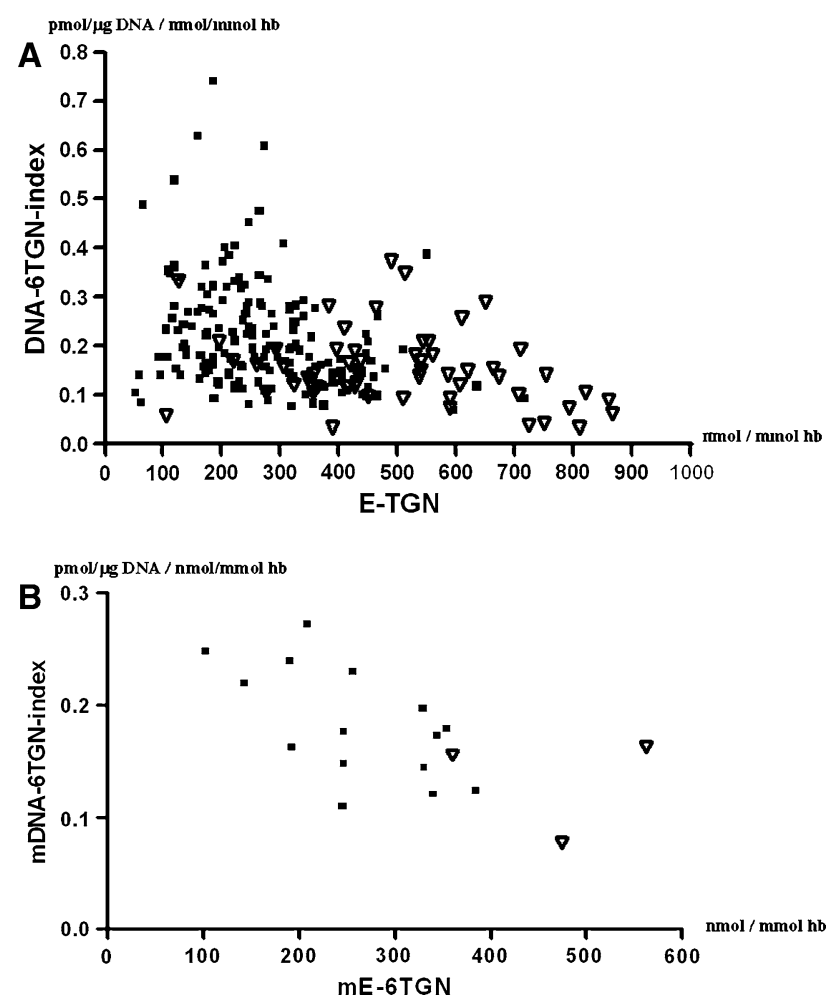

Fig. 3 a E-6TGN versus DNA-6TGN index in individual blood samples. The DNA-6TGN index was inversely correlated to E-6TGN, which implies that with increasing levels of E-6TGN relatively less 6TGN were incorporated into DNA. Inverted triangle TPMT heterozygous patients, filled square TPMT homozygous patients. b mE-6TGN versus mDNA-6TGN index. The mDNA-6TGN index was inversely correlated to mE-6TGN, which implies that with increasing levels of $\mathrm{mE}-6 \mathrm{TGN}$ relatively less 6TGN were incorporated into DNA. Inverted triangle TPMT-heterozygous patients, filled square TPMT-homozygous patients

that with high levels of MeMP there is an enhanced incorporation of 6TGN into the DNA as measured by DNA-6TGN index (Fig. 4). Furthermore, meanE-MeMP was significantly inversely correlated to E-6TGN $\left(r_{\mathrm{p}}=-0.48\right.$, $p=0.04)$, the TPMT activity $\left(r_{\mathrm{p}}=0.63, p=0.009\right)$, but not to DNA-6TGN $\left(r_{\mathrm{p}}=-0.14, p=0.18\right)$.

meanE-MTX was not significantly correlated with meanE-6TGN $\left(r_{\mathrm{p}}=0.04, p=0.89\right)$, meanDNA-6TGN $\left(r_{\mathrm{p}}=\right.$ $-0.31, p=0.22)$, meanDNA-6TGN index $\left(r_{\mathrm{p}}=-0.37\right.$, $0.13)$, TPMT-genotype $\left(r_{\mathrm{p}}=0.32, p=0.20\right)$, meanTPMT activity $\left(r_{\mathrm{p}}=-0.04, p=0.88\right)$, or meanE-MeMP $\left(r_{\mathrm{p}}=0.05\right.$, $p=0.84)$.

\section{Discussion}

Maintenance therapy of childhood ALL and NHL is traditionally monitored and adjusted by the degree of myelosuppression [3] which reflects the assumption that efficacy and toxicity are interrelated, and that myelosuppression is required for a successful anticancer effect [2]. The treatment intensity obtained during maintenance therapy reflects the dose adjustment guidelines of the relevant protocol, individual drug disposition, and the compliance to the protocol by both the physician and the patient $[20,21]$.

TPMT homozygous patients have an increased risk of relapse, probably due to their reduced formation of 6TGN [6, 22]. In contrast, TPMT heterozygous patients produce higher E-6TGN and DNA-6TGN levels, and these patients experience enhanced myelosuppression at standard 6MPdosage, necessitating a substantial dosage reduction to avoid severe toxic effects [22-24]. The majority of clinical studies have used E-6TGN as a surrogate parameter for DNA-6TGN levels in nucleated cells [9-12], but dose adjustments of maintenance therapy by E-6TGN have failed to reduce relapse rates [25].

This present in vivo study indicates that DNA-6TGN levels may be useful for monitoring 6MP/MTX maintenance therapy, since it combines the effects of 6TGN and MeMP levels. Furthermore, the DNA-6TGN plateau reached at high levels of mE-6TGN may explain why TPMT low activity patients can tolerate very high E-6TGN levels without unacceptable myelosuppression, since our data imply that with increasing mE-6TGN levels the relative incorporation ratio into DNA decreases.

Me-TIMP is known to be a powerful inhibitor of the purine de novo synthesis and can thus potentiate the incorporation of 6TGN into DNA [26]. This may explain why TPMT heterozygous and TPMT-deficient patients have and tolerate very high E-6TGN levels compared to the TPMT wild-type patients, when both are adjusted to 6MP doses that give acceptable myelotoxicity, since this can probably reflect that the TPMT low activity group lack or have very reduced levels of Me-TIMP [23, 25, 31]. Thus, both

Table 2 Median and mean values on the included 18 patients

\begin{tabular}{lll}
\hline & Median concentration & Mean concentration \\
\hline E-6TGN & $284 \mathrm{nmol} / \mathrm{mmol} \mathrm{hb}($ range 51-864) & $295.63 \mathrm{nmol} / \mathrm{mmol} \mathrm{hb} \mathrm{(range} \mathrm{103.28-563.66)}$ \\
DNA-6TGN & $0.52 \mathrm{pmol} \mathrm{6TGN/ \mu g} \mathrm{DNA} \mathrm{(range} \mathrm{0.05-2.12)}$ & $0.48 \mathrm{pmol} 6 \mathrm{TGN} / \mu \mathrm{g}$ DNA (range 0.26-0.91) \\
DNA-6TGN index & $0.18 \mathrm{p} \mathrm{mol} / \mu \mathrm{gg} / \mathrm{nmol} / \mathrm{mmol}$ DNA (range 0.032-0.74) & $0.17 \mathrm{pmol} / \mu \mathrm{g} / \mathrm{nmol} / \mathrm{mmol} \mathrm{DNA(range} \mathrm{0.08-0.27)}$ \\
MeMP & $5.579 \mathrm{nmol} / \mathrm{mmol} \mathrm{hb} \mathrm{(range} \mathrm{172-25,830)}$ & $6,528.39 \mathrm{nmol} / \mathrm{mmol} \mathrm{hb} \mathrm{(range} \mathrm{482.61-18,040.37)}$ \\
\hline
\end{tabular}



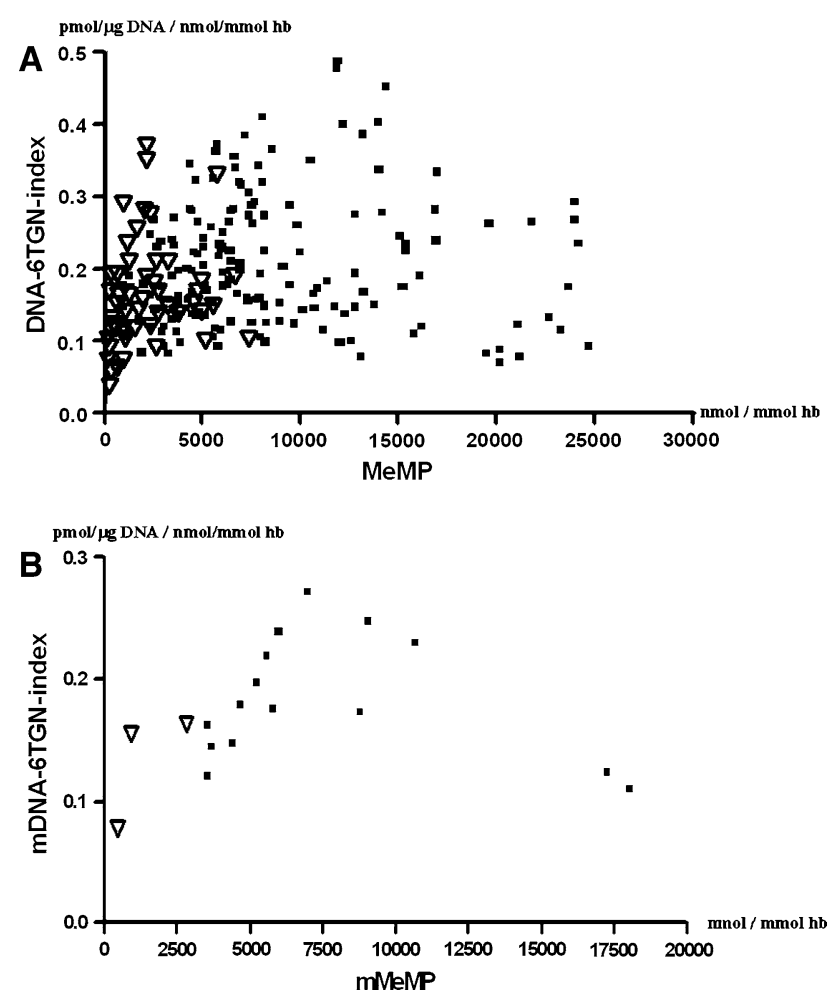

Fig. 4 a MeMP versus DNA-6TGN index in individual blood samples. MeMP were significantly correlated to DNA-6TGN index indicating that with high levels of MeMP there was a significant increase in the relative incorporation of 6TGN into DNA. Inverted triangle TPMT heterozygous patients, filled square TPMT homozygous patients. b mMeMP versus mDNA-6TGN index. mMeMP were significantly correlated to mDNA-6TGN index indicating that with high levels of MeMP there was a significant increase in the relative incorporation of 6TGN into DNA. Inverted triangle TPMT heterozygous patients, filled square TPMT homozygous patients

patients with high intracellular 6TGN levels and patients with high MeMP will have enhanced 6TGN incorporation into DNA.

We found a wide interindividual and intraindividual variation in the pharmacokinetic variables (data not shown), which could be explained by individualized dosing of 6MP and MTX depending on body surface area and bone marrow suppression.

To our knowledge, this is the first in vivo study of childhood lymphoblastic malignancies where DNA-6TGN has been measured in nucleated cells. The findings are in line with in vitro results of methylated thiopurine metabolites being significantly correlated to the incorporation of 6TGN into the DNA [5]. The results of the present study may explain why patients with low E-MeMP (such as TPMT heterozygous or deficient patients) tolerate high levels of cytosol E-6TGN without excessive myelotoxicity, but develop severe toxicity when exposed to high-dose MTX $[23,27]$. Secondly, it may explain why not only patients with low TPMT activity and/or very high E-6TGN levels, but also those with high E-MeMP levels could have an increased risk of therapy-related second AML/myelodysplasia because of enhanced DNA-6TGN incorporation $[28,29]$. Thirdly, it could explain why attempts to improve the efficacy of thiopurine therapy by giving 6-thioguanine instead of 6MP to children with leukaemia have failed to improve the outcome significantly. Thus, children who received 6-thioguanine had several fold higher E-6TGN levels than those who received 6MP, but they lack the methylated metabolites, which could have compromised their DNA-6TGN incorporation [30, 31]. So far, clinical data comparing DNA-6TGN incorporation in 6-thioguanine- and 6MP-treated patients are lacking.

Large prospective clinical trials are needed to explore the potential advantage of monitoring leukocyte DNA6TGN levels during 6MP/MTX maintenance therapy of childhood ALL and NHL. Such a study is part of the ongoing Nordic Society of Paediatric Haematology and Oncology ALL-2008 protocol.

Acknowledgments This study has received financial support from H:S Research Fund 2000 (Grant no. 120), the Danish Cancer Society (Grant no. 99144069132), the Danish Childhood Cancer Foundation, The University Hospital Rigshospitalet, Novo Nordic Foundation, Home Secretary Research Grant for Individualised Therapy, and Danish Research Council for Health and Disease (Grant no. 271-0615). Kjeld Schmiegelow holds the Childhood Cancer Foundation Research Professorship in Pediatric Oncology. A special thanks to Jens Bo Thomsen, who has performed the DNA-6TGN analysis and data registration.

Conflict of interest statement None.

\section{References}

1. Schmiegelow K, Gustafsson G (2005) Acute lymphoblastic leukemia. In: Caron M (ed) Cancer in children. Oxford University Press, Oxford, pp 138-170

2. Schmiegelow K, Pulczynska MK (1990) Maintenance chemotherapy for childhood acute lymphoblastic leukemia: should dosage be guided by white blood cell counts? Am J Pediatr Hematol Oncol $12: 462-467$

3. Arico M, Baruchel A, Bertrand Y, Biondi A, Conter V, Eden T, Gadner H, Gaynon P, Horibe K, Hunger SP, Janka-Schaub G, Masera G, Nachman J, Pieters R, Schrappe M, Schmiegelow K, Valsecchi MG, Pui CH (2005) The seventh international childhood acute lymphoblastic leukemia workshop report: Palermo, Italy, January 29-30, 2005. Leukemia 19:1145-1152

4. Uribe-Luna S, Quintana-Hau JD, Maldonado-Rodriguez R, Espinosa-Lara M, Beattie KL, Farquhar D, Nelson JA (1997) Mutagenic consequences of the incorporation of 6-thioguanine into DNA. Biochem Pharmacol 54:419-424

5. Bokkerink JP, Stet EH, De Abreu RA, Damen FJ, Hulscher TW, Bakker MA, van Baal JA (1993) 6-Mercaptopurine: cytotoxicity and biochemical pharmacology in human malignant T-lymphoblasts. Biochem Pharmacol 45:1455-1463

6. Schmiegelow K, Forestier E, Kristinsson J, Soderhall S, Vettenranta K, Weinshilboum R, Wesenberg F (2009) Thiopurine 
methyltransferase activity is related to the risk of relapse of childhood acute lymphoblastic leukemia: results from the NOPHO ALL-92 study. Leukemia 23:557-564

7. Wang L, Weinshilboum R (2006) Thiopurine S-methyltransferase pharmacogenetics: insights, challenges and future directions. Oncogene 25:1629-1638

8. Lilleyman JS, Lennard L (1994) Mercaptopurine metabolism and risk of relapse in childhood lymphoblastic leukaemia. Lancet 343:1188-1190

9. Erb N, Harms DO, Janka-Schaub G (1998) Pharmacokinetics and metabolism of thiopurines in children with acute lymphoblastic leukemia receiving 6-thioguanine versus 6-mercaptopurine. Cancer Chemother Pharmacol 42:266-272

10. Relling MV, Hancock ML, Boyett JM, Pui CH, Evans WE (1999) Prognostic importance of 6-mercaptopurine dose intensity in acute lymphoblastic leukemia. Blood 93:2817-2823

11. Schmiegelow K, Schroder H, Gustafsson G, Kristinsson J, Glomstein A, Salmi T, Wranne L (1995) Risk of relapse in childhood acute lymphoblastic leukemia is related to RBC methotrexate and mercaptopurine metabolites during maintenance chemotherapy. Nordic Society for Pediatric Hematology and Oncology. J Clin Oncol 13:345-351

12. Lennard L (2001) Therapeutic drug monitoring of cytotoxic drugs. Br J Clin Pharmacol 52:75-87

13. Gustafsson G, Schmiegelow K, Forestier E, Clausen N, Glomstein A, Jonmundsson G, Mellander L, Makipernaa A, Nygaard R, Saarinen-Pihkala UM (2000) Improving outcome through two decades in childhood ALL in the Nordic countries: the impact of high-dose methotrexate in the reduction of CNS irradiation. Nordic Society of Pediatric Haematology and Oncology (NOPHO). Leukemia 14:2267-2275

14. Miller SA, Dykes DD, Polesky HF (1988) A simple salting out procedure for extracting DNA from human nucleated cells. Nucleic Acids Res 16:1215

15. Bruunshuus I, Schmiegelow K (1989) Analysis of 6-mercaptopurine, 6-thioguanine nucleotides, and 6-thiouric acid in biological fluids by high-performance liquid chromatography. Scand J Clin Lab Invest 49:779-784

16. Erdmann GR, Steury JC, Carleton BC, Stafford RJ, Bostrom BC, Canafax DM (1991) Reversed-phase high-performance liquid chromatographic approach to determine total lymphocyte concentrations of 6-thioguanine, methylmercaptopurine and methylthioguanine in humans. J Chromatogr 571:149-156

17. Kamen BA, Takach PL, Vatev R, Caston JD (1976) A rapid, radiochemical-ligand binding assay for methotrexate. Anal Biochem 70:54-63

18. Siegel S, Castellan NJ (1988) Non-parametric statistics for the behavioral science. McGraw-Hill, Singapore

19. Cleveland WS, Devlin SJ (1988) Locally weighted regression: an approach to regression analysis by local fitting. J Am Stat Assoc 83:596-610
20. Peeters M, Koren G, Jakubovicz D, Zipursky A (1988) Physician compliance and relapse rates of acute lymphoblastic leukemia in children. Clin.Pharmacol Ther 43:228-232

21. Lancaster D, Lennard L, Lilleyman JS (1997) Profile of noncompliance in lymphoblastic leukaemia. Arch Dis Child 76:365-366

22. Lennard L, Van Loon JA, Weinshilboum RM (1989) Pharmacogenetics of acute azathioprine toxicity: relationship to thiopurine methyltransferase genetic polymorphism. Clin Pharmacol Ther 46:149-154

23. Relling MV, Hancock ML, Rivera GK, Sandlund JT, Ribeiro RC, Krynetski EY, Pui CH, Evans WE (1999) Mercaptopurine therapy intolerance and heterozygosity at the thiopurine S-methyltransferase gene locus. J Natl Cancer Inst 91:2001-2008

24. Cuffari C, Dassopoulos T, Turnbough L, Thompson RE, Bayless TM (2004) Thiopurine methyltransferase activity influences clinical response to azathioprine in inflammatory bowel disease. Clin Gastroenterol Hepatol 2:410-417

25. Schmiegelow K, Bjork O, Glomstein A, Gustafsson G, Keiding N, Kristinsson J, Makipernaa A, Rosthoj S, Szumlanski C, Sorensen TM, Weinshilboum R (2003) Intensification of mercaptopurine/ methotrexate maintenance chemotherapy may increase the risk of relapse for some children with acute lymphoblastic leukemia. J Clin Oncol 21:1332-1339

26. Krynetski EY, Tai HL, Yates CR, Fessing MY, Loennechen T, Schuetz JD, Relling MV, Evans WE (1996) Genetic polymorphism of thiopurine S-methyltransferase: clinical importance and molecular mechanisms. Pharmacogenetics 6:279-290

27. Andersen JB, Szumlanski C, Weinshilboum RM, Schmiegelow K (1998) Pharmacokinetics, dose adjustments, and 6-mercaptopurine/methotrexate drug interactions in two patients with thiopurine methyltransferase deficiency. Acta Paediatr 87:108-111

28. Bo J, Schroder H, Kristinsson J, Madsen B, Szumlanski C, Weinshilboum R, Andersen JB, Schmiegelow K (1999) Possible carcinogenic effect of 6-mercaptopurine on bone marrow stem cells: relation to thiopurine metabolism. Cancer 86:1080-1086

29. Schmiegelow K, Al-Modhwahi I, Andersen MK, Behrendtz M, Forestier E, Hasle H, Heyman M, Kristinsson J, Nersting J, Nygaard R, Svendsen AL, Vettenranta K, Weinshilboum R (2009) Methotrexate/6-mercaptopurine maintenance therapy influences the risk of a second malignant neoplasm after childhood acute lymphoblastic leukemia: results from the NOPHO ALL-92 study. Blood 113:6077-6084

30. Harms DO, Gobel U, Spaar HJ, Graubner UB, Jorch N, Gutjahr P, Janka-Schaub GE (2003) Thioguanine offers no advantage over mercaptopurine in maintenance treatment of childhood ALL: results of the randomized trial COALL-92. Blood 102:2736-2740

31. Vora A, Mitchell CD, Lennard L, Eden TO, Kinsey SE, Lilleyman J, Richards SM (2006) Toxicity and efficacy of 6-thioguanine versus 6-mercaptopurine in childhood lymphoblastic leukaemia: a randomised trial. Lancet 368:1339-1348 